\title{
URGENSI LAGU KIDS BERBASIS TRI HITA KARANA DIIMPLEMENTASIKAN DI SEKOLAH TK SARI MEKAR SUKAWATI DAN TK SUTHA DHARMA UBUD
}

\author{
Oleh: \\ I Gusti Ayu Suasthi, I Gusti Ketut Widana, Ni Made Surawati \\ ayusuasthi@gmail.com \\ Prodi Pendidikan Agama Hindu \\ Fakultas Pendidikan Universitas Hindu Indonesia Denpasar
}

Proses Review 20 Agustus-14 September, Dinyatakan Lolos 22 September

\begin{abstract}
This article discusses the urgency of the Tri Hita Karana-based Kids song which is implemented at TK (Kindegarten) Sari Mekar Sukawati Kindergarten and TK Sutha Dharma Ubud. In addition to document studies, this research data was obtained through observation and interviews with teachers at TK Sari Mekar Sukawati and TK Sutha Dharma Ubud which were then processed and presented in descriptive-qualitative form. The results of the study show that: first, introducing the concepts of Hinduism, especially the Tri Hita Karana teachings, will be easier if they are integrated into singing while learning. Second, building children's emotional intelligence from an early age will help children more easily understand the messages in songs. The lyrics of children's songs contain messages to educate the mind and faith intelligence. For example, the song Pelangi-pelangi instills children to believe in the greatness and omnipotence of Ida Sang Hyang Widhi/God in the Tri Hita Karana concept, including the parhyangan aspect. The song Satu-Satu Aku Sayang Ibu contains the meaning of loving each other, this is part of the pawongan teachings. As well as the song Lihat Kebunku teaches children to care for plants, this reflects the attitude of loving plants / nature as part of the teachings of Palemahan.
\end{abstract}

Keywords: Kids Songs, Tri Hita Karana, Implementation

\begin{abstract}
Abstrak
Artikel ini membahas Urgensi Lagu Kids Berbasis Tri Hita Karana Diimplementasikan di Sekolah Tk Sari Mekar Sukawati dan Tk Sutha Dharma Ubud. Di samping studi dokumen, data penelitian ini diperoleh melalui observasi dan wawancara dengan para guru di sekolah TK Sari Mekar Sukawati dan TK Sutha Dharma Ubud. Data yang terkumpul kemudian diolah dan disajikan dalam bentuk deskriptif-kualitatif. Hasil kajian menunjukkan bahwa: pertama, mengenalkan konsep-konsep ajaran agama Hindu khususnya ajaran tri hita karana akan lebih mudah bila diintegrasikan dalam
\end{abstract}


kegiatan bernyanyi sambil belajar. Kedua, membangun kecerdasan emosi anak sejak usia dini akan membantu anak lebih mudah memahami pesan-pesan yang ada dalam lagu. Lirik pada lagu anakanak banyak mengandung pesan untuk mencerdaskan akal pikiran dan kecerdasan iman. Sebagai contoh lagu Pelangi-pelangi menanamkan anak-anak untuk percaya akan kebesaran dan kemahakuasaan Ida Sang Hyang Widhi/Tuhan dalam konsep tri hita karana termasuk dalam aspek parhyangan. Lagu Satu-satu Aku Sayang Ibu mengandung makna saling menyayangi antar sesama, hal ini bagian dari ajaran pawongan. Serta lagu Lihat Kebunku mengajarkan pada anak-anak untuk merawat tumbuhan, hal ini mencerminkan sikap menyayangi tumbuhan/alam sebagai bagian dari ajaran palemahan

Kata kunci: Lagu Kids, Tri Hita Karana, Implementasi

\section{PENDAHULUAN}

Bernyanyi adalah aktifitas musikal yang pengekspresiannya melalui alunan-alunan musik yang berada pada perasaan dan pikiran pribadi manusia, dan bernyanyi sendiri bersifat secara langsung. Selain itu bernyanyi juga memiliki makna pengekspresian yang natural dan aristik, karena musik merupakan bahasa emosi yang memberi kesenangan dan kepuasan pada diri sendiri. Beda halnya jika bernyanyi kita ajarkan kepada Anak Usia Dini. Lagu kids atau nyanyian anak-anak berupa syair dan musik merupakan salah satu metode yang dapat digunakan dalam proses pembelajaran pada anak usia dini. Kendall (dalam Seefeldt 2008:311) menjelaskan setiap kebudayaan mempunyai lagu-lagu rakyatnya sendiri. Dengan memperkenalkan ini kepada anak-anak, para guru tidak hanya menunjukkan rasa hormat dan penghargaan bagi kebudayaan orang lain tetapi juga memperlihatkan kepada anak-anak bahwa semua kebudayaan dipersatukan lewat lagu dan musik.

Khususnya pembelajaran agama lagu atau musik yang memiliki berbagai elemen (nada, syair) didalamnya dapat dijadikan salah satu instrument untuk memperkaya wawasan pengetahuan (struktur kognisi) anak usia dini melalui kegiatan bernyanyi dapat memperkaya kehidupan rohani (aspek afeksi), sehingga dengan bernyanyi anak dapat mengungkapkan buah pikiran dan perasaan hatinya serta dapat mengendalikan emosinya. Bernyanyi dapat menciptakan suasana belajar yang aktif, kreatif, dan menyenangkan.
Bernyanyi juga dapat mendidik anak melakukan aktivitas mengeluarkan suara dengan syair-syair yang dilakukan. Biasanya syair-syair tersebut disesuaikan dengan materimateri yang diajarkan. Dengan bernyanyi dipercaya dapat membuat suasana belajar menjadi riang dan bergairah sehingga perkembangan anak dapat distimuli lebih optimal. Pada prinsipnya lembaga PAUD adalah tempat pengembangan seluruh aspek dalam diri anak meliputi fisik - motorik, sosial emosional, intelektual, bahasa dan seni, serta moral dan agama.

Sesuai dengan prinsip - prinsip teori belajar humanistik, yang menekankan pencapaian tujuan belajar "Memanusiakan Manusia". Proses pembelajaran mengacu dan mendukung tujuan untuk penguatan jati diri melalui sraddha dan bhakti. Mengembangkan potensi pribadi dan serasi dengan dirinya, membina agar mampu mempraktekkan agama di lingkungannya. Dapat merencanakan masa depan yang lebih dalam menghadapi era global, tanpa tercabut dari akar budaya dan kepercayaannya, yang dicerahi ajaran Tri Hita Karana.

Pendidikan karakter bersifat humanis religius, tidak ada pemaksaan pada perkembangan jasmani dan rohani. Pendidikan bersumber pada anak didik, anak yang tumbuh berkembang alami. Pembelajaran pada anakanak adalah mengelola kondisi anak yang suka bermain, berteriak dan bergerak dan menemukan pemahaman melalui laboratium alam. Dalam kerangka memanusiakan manusia, peranan guru pada pembelajaran adalah bagaimana seorng guru itu malayani untuk 
mengembangkan dan memperkaya potensi siswa dengan mempertimbangkan faktor, biologis, psikologis, sosiologis, ekologis dari siswa tersebut.

\section{METODE PENELITIAN}

Rancangan penelitian ini adalah penelitian kualitatif. Sumber data primernya berupa katakata dan ungkapan, sementara data sekunder meliputi data tertulis berupa buku, pustaka, dan sebagainya. Teknik pengumpulan datanya dibagi menjadi tiga yakni observasi, wawancara dan studi dokumen. Analisis data dilakukan secara deskriptif.

\section{PEMBAHASAN}

\subsection{Hakikat Bernyanyi}

Bermain sambil bernyanyi dua hal yang melekat dalam kehidupan anak usia dini. Pemilihan lagu yang tepat sesuai dengan perkembangan psikologis dan lingkungan di mana anak tumbuh, membantu anak dalam memahami materi pelajaran. Menyampaikan materi pelajaran agama khususnya ajaran tri hita karana pada anak usia dini, akan lebih mudah dipahami dengan memberikan melalui gubahan lagu yang sudah biasa didengar anak sejak usia dini. Melalui gubahan lagu kids berwawasan tri hita karana yang bersifat universal diharapkan dapat membangun karakter anak "genius", yaitu anak yang gesit, empati, berani, unggul, dan sehat. Anak unggul dengan rajin berdoa/bersembahyang sebagai cerminan aspek prahyangan, anak memiliki sikap empati dan berani sebagai cermin aspek pawongan, dan anak yang gesit dan sehat sebagai cerminan aspek palemahan.

Sebagaimana Savira (2018:dalam kompasiana.com) bernyanyi adalah bagian yang penting dalam pengembangan diri anak. Guru di taman kanak-kanak juga berkewajiban untuk mengajarkan berbagai nyanyian kepada anak didiknya, hal ini bukan mengarahkan anak untuk menjadi penyanyi, akan tetapi bagaimana membuat anak menjadi antusias dalam bernyanyi. Mengapa? Karena bernyanyi adalah salah satu bentuk mengekspresikan apa yang dirasakan dan dipikirkan oleh seorang anak untuk bersentuhan dengan sesuatu yang indah dan ber-melody. Kamtini (2005:113) Bernyanyi merupakan sarana pengungkapan pikiran dan perasaan, sebab kegiatan bernyanyi penting bagi pendidikan anak-anak selain itu bernyanyi adalah kegiatan menyenangkan yang memberi kepuasan kepada anak- anak.

Dari hasil observasi peneliti, disaat berbaris akan masuk kelas, pada saat anak-anak bernyanyi guru sudah berupaya untuk mengajak anak-anak agar mau bernyanyi. Tetapi masih saja ada 3-5 anak yang lain-lain, karena merasa tidak tertarik atau bosan menyanyikan lagu tersebut (Disini Senang, Disana Senang). Guru terus berupaya dengan mendekati anak-anak tersebut agar mau bernyanyi, mengubah suasana hati anak lebih tenang, lebih fokus dan lebih begembira. Dapat disimpulkan bahwa kegiatan bernyanyi pada anak sekolah TK/PAUD akan menimbulkan suasana pembelajaran yang lebih menyenangkan, menggairahkan, dan membuat anak-anak merasa senang, terhibur, dan lebih bersemangat. Metode bernyanyi bukanlah bermaksud membentuk anak menjadi penyanyi, karena para guru paham bahwa masing-masing anak mempunyai cara yang berbeda dalam mengepresikannya. Ada anak yang dengan cepat dapat menangkap nyanyian yang diberikan, dan sebaliknya ada yang lambat bahkan ada pula yang sama sekali tidak mau bernyanyi.

Nyanyian disini merupakan bagian kehidupan dan perkembangan jiwa setiap manusia. Sejak di dalam kandungan seorang anak telah memiliki beberapa aspek yang berkaitan dengan musik. Aspek itu diterima dan dipengaruhi oleh berbagi pengalaman yang bersifat natural atau alami dalam proses kehidupannya. Sehingga sebuah nyanyian atau lagu itu dapat berdampak kedalam diri seseorang. Pada kegiatan bernyanyi selalu mempertimbangkan syair lagu yang mengandung nilai-nilai norma yang perlu dipahami anak. Hal ini dapat membantu anak membedakan yang baik dan buruk, serta melatih pembiasaan hal-hal yang baik. Kebiasaan yang baik ditanamkan sejak kecil dan diperkuat saat anak sekolah di TK/PAUD, sangat bermanfaat bagi perkembangan kecerdasan emosi dan karakter anak, sebagaimana Suasthi (2017:62) menguraikan sebagai berikut. 
Menurut para ahli psikologi, bahwa perkembangan emosi seseorang 50\% sudah terjadi ketika anak berumur 5 tahun, 30\% terjadi perkembangan ketika menjelang umur 8 tahun. Antara usia 8 18 tahun perkembangan emosi bertambah lagi 15\%. Ini berarti anak sampai usia 18 tahun sudah mengalami perkembangan kecerdasan moral (SQ) mencapai 95\%. Dalam hal ini masih tersisa 5\% dari manusia agar digunakan dengan sebaiknya untuk mencapai apa yang menjadi cita-citanya (agar dapat hidup sukses).

Senada dengan penjelasan diatas $\mathrm{Ni}$ Nyoman Kembar Dewi guru TK sari Mekar menyatakan bahwa melalui kegiatan bernyanyi dapat menstimulasi perkembangan otak anak, anak akan lebih mudah mengingat pesan-pesan pembelajaran lewat nada lagu yang dinyanyikan. di dalam lagu dan musik dapat membantu meningkatkan kemampuan otak terutama dalam hal mengingat dan konsentrasi, sehingga perkembangan otak anak dapat berlangsung secara optimal dan dapat membantu menyeimbangkan kemampuan otak kanan dan otak kiri. (wawancara, 12 Februari 2020)

Dari hasil pengamatan peneliti di sekolah TK Sari Mekar pada tanggal 14 Februari 2020 saat guru menyampaikan tema menekankan pada norma/nilai perbuatan baik-buruk, penentuan tema lagu tidak dekat dengan situasi anak atau belum bersifat kontekstual. Guru harus memilih atau menggubah lagu supaya anak dapat melihat dan merasakan langsung tentang apa yang disampaikan oleh guru. Seperti anak yang tinggal di suasana pedesaan khususnya di Desa Sukawati yang kaya dengan tradisi seni budaya dapat dijadikan contoh dalam syair lagu. Guru yang mampu menyampaikan tema melalui lagu yang dekat dengan suasana lingkungan anak, maka anak akan lebih mudah mengingat apa yang disampaikan oleh guru. Saat guru menyampaikan tema baru dan disesuaikan dengan pengalaman anak, artinya guru sudah mengupayakan agar otak kanan dan otak kiri anak berkembang secara optimal.

\subsection{Manfaat Bernyanyi Bagi Anak}

Menggunakan metode bernyanyi saat menyampaikan materi pelajaran khususnya mengenalkan ajaran agama dapat dikatakan sangat tepat. Bernyanyi merupakan salah satu bagian yang penting dalam kehidupan. Para ahli psikologi menjelaskan bahwa anak usia 3 bulan dalam kandungan sudah dapat mendengar melalui stimulasi ibunya. sehingga bernyanyi memiliki fungsi sebagai sarana untuk menenangkan seorang anak. Sebagai contoh ketika anak menangis atau rewel maka orangtua akan menyanyikan lagu untuk anaknya sampai anaknya tertidur. Menggunakan nyanyian dapat membuat anak lebih tenang dan membuat anak merasa nyaman, serta suasana hati menjadi bahagia.

\subsubsection{Anak Cepat Menyerap Materi Pembelajaran}

Demikian halnya bagi anak-anak di sekolah TK para guru akan berusaha memilih lagu-lagu yang syairnya sesuai dengan tema pembelajaran yang akan disampaikan pada anak-anak agar lebih mudah dimengerti dan mudah dipahami anak sebagaimana yang disampaikan oleh $\mathrm{Ni}$ Made Kembar Wati sebagai berikut.

Dengan metode menyanyi inilah seorang anak akan lebih cepat menyerap sesuatu yang sedang diajarkan. Selain itu, bernyanyi pun memiliki fungsi sebagai sarana untuk menenangkan seorang anak. Karena dapat menenangkan, maka alangkah baiknya jika guru menyanyikan beberapa lagu saat seorang anak berisik dan membuat suara suara gaduh. Cara tersebut akan jauh lebih baik dibandingkan bila guru marah-marah yang justru membuat anak menjadi stres oleh ucapan guru. Apalagi jika guru sampai mengucapkan kata kata yang tidak seharusnya diketahui oleh seorang anak. Namun dengan bernyanyi dan nyanyian, bisa menenangkan anak tanpa harus berteriak dan marah marah. Salah satu cara yang cukup efektif untuk mempercepat seorang anak dalam 
menangkap materi pelajaran adalah dengan menggunakan metode menyanyi. Melalui metode yang satu ini, belajar menjadi sebuah kegiatan yang menyenangkan dan selalu ditunggu tunggu. Hal ini akan sangat baik untuk perkembangan seorang anak, dia akan lebih cepat menerima pelajaran karena suasana belajar yang menyenangkan. (wawancara, 15 Februari 2020)

Suyadi (2010:229) menguraikan sebagai berikut, konsep dasar edutainment berupaya agar pembelajaran yang terjadi berlangsung dalam suasana yang kondusif dan menyenangkan. Suasana gembira akan mempengaruhi cara otak dalam memproses, menyimpan, dan mengambil informasi dengan mudah. Dalam upaya menciptakan kondisi ini maka konsep edutainment mencoba memadukan pendidikan dan hiburan. Ketika suatu pelajaran melibatkan emosi positif yang kuat, umumnya pelajaran tersebut akan terekam dengan kuat pula dalam ingatan. Oleh karena itu, dibutuhkan kreativitas guru dan orangtua untuk menciptakan permainan-permainan yang dapat menjadi wadah dan sarana anak untuk belajar, misalnya melalui bernyanyi, drama, mewarnai, humor dan lain-lain. Menurut Vernon A. Magnesen (Suyadi 2010:230) dalam Quantum Teaching, belajar $10 \%$ dari apa yang kita baca; $20 \%$ dari apa yang kita dengar; 30\% dari apa yang kita lihat; $50 \%$ dari apa yang dilihat dan didengar; $70 \%$ dari apa yang dikatakan; dan 90\% dari apa yang dikatakan dan dilakukan.

Potensi rohaniah atau yang disebut tri pramana, yaitu sabda/perilaku, bayu/kehendak, idep/pikiran. Di pihak lainpotensi jasmaniah meliputi unsur panca mahabutha, (pertiwi/ tulang, apah/air, darah, teja/panas tubuh, bayu/ napas, akasa/rongga dada, mulut), yaitu lima unsur yang memengaruhi tumbuh kembang anak. Apabila anak mendapat asupan gizi yang baik, anakakan tumbuh menjadi anak sehat. Anak yang sehat merupakan modal untuk menjadi anak yang cerdas. Dalam pandangan agama Hindu anak yang cerdas disebut anak yang wiweka, yaitu anak yang memiliki kemampuan untuk mempertimbangkan dampak positif dan negatif semua perbuatannya.
Oleh karena itu, usaha pengembangan potensi ini harus diutamakan agar dapat menjadi landasan bagi tumbuh kembang potensi yang lain. Selain itu, hendaklah dilaksanakan secara nyata oleh orangtua agar potensi yang ada pada diri anak dapat tumbuh dan berkembang secara wajar, selaras, dan seimbang.

\subsubsection{Meningkatkan Rasa Percaya Diri}

Menyanyi dapat meningkatkan kepercayaan diri anak. Menyanyi juga terbukti dapat meningkatkan kepercayaan diri pada anak. Anak merasa memiliki kemampuan untuk dibanggakan dan ditunjukkan kepada orang lain. Saat mereka berhasil menyelesaikan sepotong lagu dan mendapat tanggapan yang positif dari orang tua atau guru, kepercayaan diri mereka akan semakin meningkat. Menyanyi pada anak preschool dan anak TK dapat memberikan pengalaman baru bagi mereka. Menyanyi yang dilakukan bersama-sama di sekolah dapat membantu mereka berkolaborasi, berbagi, serta meningkatkan kreativitas dan kemampuan konsentrasi. Menyanyi juga dapat mempermudah anak memasuki lingkungan baru sekolah dan membuat mereka tidak merasa asing dengan teman-teman barunya.

Akhirnya perlu juga diperhatikan bahwa lingkungan yang lebih banyak bersifat mengajak, mengundang atau memberi kesempatan akan lebih efektif daripada lingkungan yang ditandai dengan larangan-larangan, peraturan-peraturan yang serba membatasi. Para aliran behavorisme yang dipelopori oleh Pavlop dan B. F. Skiner, berpendapat bahwa manusia itu dilahirkan sebagai sebuah "tabula rasa" yaitu sebagai kertas yang kosong. Karena itu dari dirinya sendiri, individu itu netral ketika dilahirkan. Tingkah laku dan kepribadian manusia terbentuk dan tersusun dari kebiasaankebiasaan yang dipelajari dari lingkungannya. Sebagaimana disampaikan oleh Putu Eka Riskayanti, guru TK Sari Mekar sebagai berikut. Pada umumnya anak-anak baru memasuki sekolah mengalami hambatan dalam bersosialisasi. Namun dalam kurun waktu tiga sampai enam bulan sebagian besar anak-anak sudah mulai tumbuh rasa percaya dirinya. Kami berusaha membantu anak-anak dengan 
membimbing melalui kegiatan bernyanyi bersama atau menunjuk anak diminta untuk kedepan bernyanyi. Sehingga lambat laun akan tumbuh rasa percaya diri pada anak. Demikian pula Menyanyi juga terbukti dapat meningkatkan kepercayaan diri pada anak. Anak merasa memiliki kemampuan untuk dibanggakan dan ditunjukkan kepada orang lain. Saat mereka berhasil menyelesaikan sepotong lagu dan mendapat tanggapan yang positif dari orang tua atau guru, kepercayaan diri mereka akan semakin meningkat. Kami para guru sangat didukung oleh para orangtua siswa dalam membimbing putra-putrinya. (wawancara, 20 Februari 2020)

\subsubsection{Menambah Kemampuan Berbahasa}

Bahasa merupakan alat untuk berkomunikasi, dapat diartikan sebagai tanda gerak dan suara untuk menyampaikan isi pikiran kepada orang lain. Pada anak sejak usia dini sudah ditanamkan untuk menguasai kosakata yang benar secara lisan. Hal ini berarti anak sudah dapat mengungkapkan keinginannya, pendapatnya, maupun penolakannya dengan menggunakan bahasa lisan. Menurut Jamaris (2006:30) Anak TK berada dalam fase perkembangan bahasa secara ekspresif. Hal ini berarti bahwa anak telah dapat mengungkapkan keinginannya, penolakannya, maupun pendapatnya dengan menggunakan bahasa lisan. Bahasa lisan sudah dapat digunakan sebagai alat berkomunikasi. 1) Kosa kata. Seiring dengan perkembangan anak dan pengalamannya berinteraksi dengan lingkungannya, kosa kata anak berkembang. 2) Sintak (tata bahasa). Anak belum mempelajari tata bahasa akan tetapi melalui contoh-contoh berbahasa yang didengar dan dilihat anak dilingkungannya. 3) Semantik. Semantik maksudnya penggunaan kata sesuai dengan tujuannya. Anak-anak sudah dapat mengekspresikan keinginan, penolakan dan pendapatnya dengan mengguanakan kata-kata dan kalimat yang tepat. 4) Fonem. Anak-anak sudah memiliki kemampuan untuk merangkaikan bunyi yang didengarkan menjadi salah satu kata yang menggandung arti.
Demikian pula, terkait manfaat bernyanyi bagi anak hasil wawancara dengan $\mathrm{Ni}$ Wayan Warsiti menguraikan sebagai berikut.

Pada saat anak-anak bernyanyi kami para guru berusaha memilih lagu-lagu yang sesuai dengan tema pembelajaran yang akan disampaikan. Jika akan mengenalkan konsep-konsep ajaran agama, khususnya ajaran tri hita karana kami tidak menjelaskan arti dari tri hita karana. Melainkan kami akan menyesuaikan topik dengan tema yang sedang dirancang pada setiap semester dan diterapkan sesuai dengan jadwal program semester. Seperti misalnya kami akan memilih lagu dengan tema: 1) diriku sendiri, 2) kebutuhanku, 3) lingkunganku, 4) rekreasi, 5) pekerjaan, 6) alat komunikasi, semua tema ini menekankan pada unsur pawongan. Sedangkan pada unsur palemahan kami memilihkan tema misalkan: 1) alam semesta, 2) tanah airku, 3) air, udara, dan api, 4) tanaman, 5) binatang, 6) lingkunganku. Pada aspek parhyangan kami mengenalkan agama yang ada di Indonesia karena sekolah kami ada beberapa siswa yang beragama Islam, Katolik, Kristen, Buddha, sehingga secara umum kami pilihkan lagu-lagu yang menekankan pada pembentukan budi pekerti sehingga dapat diterima oleh semua anak. Misalnya dengan melakukan doa sebelum dan sesudah proses pembelajaran serta berdoa sebelum dan setelah makan. (wawancara, 2 Februari 2020)

Beberapa uraian diatas mempertegas dalam penelitian ini bahwa mengenalkan konsepkonsep ajaran agama Hindu khususnya ajaran tri hita karana akan lebih mudah bila diintregasikan dalam kegiatan bernyanyi sambil belajar. Melalui kegiatan bernyanyi suasana pembelajaran akan lebih menyenangkan, menggairahkan, membuat anak bahagia, anak menjadi terhibur, menghilangkan rasa sedih, dan anak akan lebih bersemangat. Sebagaimana, pendidikan agama Hindu di dalam tulisan ini mempunyai pengertian, yaitu usaha sadar dan terencana, menyiapkan peserta didik dalam 
mengenal, memahami, menghayati, hingga mengimani, bertakwa, berakhlak mulia dalam mengamalkan ajaran pendidikan agama Hindu dalam kehidupan sehari-hari.

Orangtua merupakan pendidik yang pertama menginternalisasi nilai-nilai agama kepada anak-anaknya untuk mengembangkan superego anak (menurut teori keperibadian Freud). Superego berkaitan dengan kemampuan anak berperilaku sesuai dengan norma-norma agama dengan menunjukkan karakter sopan santun, cinta damai, mandiri, tinggi kesadaran tentang kesehatan, berpenampilan rapi, bersih, dan mempunyai kesadaran spiritual (sifat satwam). Apabila sejak awal anak mendapat perhatian dan kasih sayang dari orang tuanya, akan tertanam dalam pikirannya untuk berusaha menjaga kehormatan diri dan kehormatan keluarga.

Orangtua yang dimaksud adalah ayah dan ibu yang melahirkan dan atau merawat dan mendidik. Di samping itu, juga membawa menuju kedewasaan dan membantu anak dalam menjalani kehidupan. Kewajiban orangtua menurut sastra Hindu yang tertuang dalam kitab Nitisastra (VIII. 3), disebut dengan panca vida terdiri atas hal-hal berikut.

1) Sang ametwaken, artinya ia yang melahirkan anak sesuai dengan kodrat untuk meneruskan generasi.

2) Sang nitya maweh bhinojana, artinya ia yang memelihara dan memberikan makan minum untuk pertumbuhan anak.

3) Sang mangupadyaya, artinya ia yang menyekolahkan putra putrinya sampai batas kemampuan orangtua.

4) Sang anyangaskara, artinya ia yangmembina mental spiritual atau karakter anak.

5) Sang matulung urip rikalaning baya, artinya ia yang memberikan jaminan keamanan kepada anaknya.

\subsubsection{Melatih Kemampuan Motorik}

Kemampuan motorik termasuk bagian dari perkembangan kecerdasan kinestetik (bodily/ kinesthetic intelligence) yang dapat dirangsang melalui gerakan, tarian, olahraga, dan terutama gerakan tubuh. Pada aspek pengembangan fisik, kompetensi dan hasil belajar yang ingin dicapai adalah kemampuan mengelola dan keterampilan tubuh termasuk gerakan-gerakan yang mengontrol gerakan tubuh, gerakan halus, dan gerakan kasar serta menerima rangsangan sensorik (pancaindera). Pada aspek pengembangan seni, kompetensi dan hasil belajar yang ingin dicapai adalah kemampuan kepekaan terhadap irama, nada, birama, berbagai bunyi, bertepuk tangan, serta menghargai hasil karya yang kreatif. (Depdiknas, 2002, 12 :15). Jadi bila anak sedang belajar, ia tidak hanya bereaksi secara intelektual melainkan juga secara emosional, ia belajar mendapatkan penambahan wawasan dan sekaligus menghayati dengan rasa senang, puas, atau rasa marah, tidak puas terhadap proses pembelajaran atau terhadap para pendidiknya. Sebagaimana kita sadari bahwa pendidikan anak usia dini yang paling dan lebih bertanggung jawab adalah orang tua, karena keluarga merupakan pendidik yang pertama dan utama. Pada era sekarang siapapun boleh ikut berpartisipasi dalam menyelenggarakan pendidikan usia dini. Dalam hal ini tugas pemerintah oleh Fasli Jalal, 2002 dalam sambutannya menyebutkan bahwa: "tugas pemerintah adalah bagaimana memfasilitasi, membina, dan mengarahkan masyarakat agar hal-hal prinsip mengenai penanganan anak usia dini yang masih sangat rentan tersebut diketahui dan diperhatikan".

Piaget (dalam Suasthi 2010:59) memandang bermain sebagai perkenalan dan arena untuk melatih motorik/otot, keterampilan fisik, keseimbangan, bekerjasama, belajar bercakapcakap belajar bahasa, persahabatan dan latihan tata krama. Anak-anak akan mendapatkan pengalaman baik suka dan sedih pada saat bermain, mereka biasanya sering berebutan untuk mendapatkan satu permainan yang sama, rasa ego mereka akan mengalami penyempurnaan, karena menyadari akan hak milik orang lain. Permainan akan memberi kepuasan emosional yang diperolehnya dari kehidupan berkelompok, anak akan mendapatkan pengakuan dari orang lain, dapat menunjukkan, prestasi dan kebebasan dalam berekspresi, sehingga dari kegiatan bermain anak banyak mendapatkan nilai positif terhadap perkembangan fisik, terampil secara motorik, 
keterampilan sosial, dan mendapatkan kepuasan emosional serta menambah tingkat kecerdasannya (intelektual). Seperti yang dikatakan guru Ni Ketut Nanik Yuliantini sebagai berikut.

Bernyanyi sambil bermain atau menggerakan anggota tubuh bagi anak bermain merupakan kegiatan yang alami dan sangat berarti/penting. Dengan bermain anak mendapatkan kesempatan mengadakan hubungan yang erat dengan lingkungan/teman sebaya, teman yang lebih tua, hewan piaraan, tanaman/ tumbuhan disekitarnya. Saat anak sedang bernyanyi, anak bisa meragakan gerakan tubuh sesuai irama lagu sebagai ungkapan perasaannya. (wawancara, 25 Februari 2020)

Jadi dapat disimpulkan bahwa kemampuan motorik merupakan sekumpulan kemampuan untuk menggunakan dan mengontrol gerakan tubuh, baik gerakan kasar maupun gerakan halus. Kemampuan yang termasuk dalam aspek motorik ini antara lain: mengangkat kepala, duduk, merangkak, berdiri, berjalan, berlari, memang beda, kelenturan pergelangan tangan, menunjuk ke sebuah titik, menggunakan jari penjepit, dan sebagainya.

\subsubsection{Membangun Kecerdasan Emosi}

Kebutuhan Emosi atau kasih sayang (asih). Pada tahun pertama kehidupan, hubungan yang mesra dan penuh kasih sayang antara anak dan ibu merupakan syarat mutlak untuk menjamin proses tumbuh kembang yang selaras baik fisik, mental maupun psikososial. Kekurangan akan kasih sayang ibu di tahun-tahun pertama pada kehidupan anak dapat mempengaruhi tumbuh kembang anak, baik fisik, mental maupun sosial anak (syndrome deprivasi maternal). Kegembiraan merupakan ekspresi emosi yang riang, bahagia, dan menyenangkan. Anak yang mengalami kegembiraan diwujudkan dengan ekspresi senyum dan gembira. Bernyanyi adalah sarana untuk mengungkapkan perasaan atau emosi jiwa, yang terkadang sulit diungkapkan dalam bentuk ucapan. Dalam hal ini dengan bernyanyi anak bisa belajar memahami emosinya, karena tidak semua lirik lagu berkenan dalam hatinya.

Membangun kecerdasan emosi anak seperti paparan diatas disampaikan oleh guru Ni Ketut Manik Yuliantini sebagai berikut.

Kami berusaha memilihkan lagu disesuaikan dengan situasi kondisi anakanak. Anak belajar tentang emosi dari syair atau lirik lagu yang didapat dalam bernyanyi bersama. Hal ini membantu anak lebih mudah merespon rasa empati, rasa senang. Kadang-kadang lagu yang dipilih mengandung nilai-nilai norma yang perlu dipahami anak. Melalui syair lagu membantu anak belajar memahami kebiasaan baik, yang ditanamkan sejak usia dini sehingga bermanfaat membangun kecerdasan emosi anak dan menjadi kebiasaan untuk pembentukan karakter anak. (wawancara, 25 Februari 2020)

Dari uraian dan wawancara diatas menunjukkan bahwa membangun kecerdasan emosi anak sejak usia dini akan membantu anak lebih mudah memahami pesan-pesan yang ada dalam lagu. Lirik pada lagu anak-anak banyak mengandung pesan untuk mencerdaskan akal pikiran dan kecerdasan iman. Sebagai contoh lagu Pelangi-pelangi menanamkan anak-anak untuk percaya akan kebesaran dan kemahakuasaan Ida Sang Hyang Widhi/Tuhan dalam konsep tri hita karana termasuk dalam aspek parhyangan. Lagu Satu-satu Aku Sayang Ibu mengandung makna saling menyayangi antar sesama, hal ini bagian dari ajaran pawongan. Serta lagu Lihat Kebunku mengajarkan pada anak-anak untuk merawat tumbuhan, hal ini mencerminkan sikap menyayangi tumbuhan/alam sebagai bagian dari ajaran palemahan. Sebagaimana Suyadi (2010:232) menguraikan sebagai berikut.

Apabila dikontekskan dengan Pendidikan Anak Usia Dini, maka pendidikan anak usia dini harus dapat merangsang dan membangun seluruh potensi kecerdasan anak, bukan mematikan potensi tersebut. Oleh karena itu, pendidik anak usia dini perlu memahami karakteristik anak yaitu: a) anak bukan miniatur orang dewasa, b) anak masih dalam tahap 
berkembang, c) setiap anak unik, d) dunia anak adalah dunia bermain, e) anak belum tahu benar salah, f) setiap karya anak berharga, g) setiap anak butuh rasa aman, h) setiap anak peneliti dan penemu.

\section{PENUTUP}

Peran orangtua sebagai pendidik yang pertama dan utama diharapkan selalu berupaya untuk meningkatkan kualitas diri agar dapat membantu perkembangan putra-putrinya sedini mungkin. Pendidikan anak usia dini tidak hanya dilakukan setelah anak lahir, tetapi juga terjadi sejak anak dalam kandungan. Hal itu sebagaimana hasil penelitian psikologi bahwa semenjak dalam kandungan ( \pm tiga bulan) anak sudah dapat merespons stimulus yang didapatkan dari luar melalui ibunya. Hal ini menggambarkan bahwa anak sudah dapat mulai menerima proses perkembangan fisik dan psikososial semenjak di dalam kandungan.

Sebagaimana dalam cerita Mahabrata diilustrasikan sebagai berikut. Tokoh Abimanyu, putra Arjuna dan Dewi Subadra, mampu menembus formasi pertahanan Cakrawyuha yang digelar Panglima Kurawa, Guru Drona. Kemampuan Abimanyu mengetahui ilmu Cakrawyuha karena saat dalam kandungan mendengar Sang Arjuna menuturkan perihal formasi perang nan unggul itu kepada Dewi Subadra perihal cara menembus pertahanan
Cakrawyuha.Akan tetapi Dewi Subadra keburu tertidur pulas sehingga jabang bayi Abimanyu kehilangan sinyal kontak untuk mengethaui kelanjutan cerita strategi perang ayahnya (Arjuna).Dengan demikian, dalam cerita Mahabrata Abimanyu hanya mampu menembus formasi lawan dan akhirnya gugur di medan perang. Dari cerita ini dapat digambarkan bahwa pendidikan nilai-nilai dan karakter anak sudah dapat dimulai sejak anak dalam kandungan.

Untuk membantu orangtua, pendidik, dan masyarakat umumnya, pendidikan anak usia dini secara resmi telah mendapat perhatian pemerintah sebagaimana tertuang dalam UU No. 20, Tahun 2003 tentang Sistem Pendidikan Nasional. Pada pasal 1 dijelaskan pengertian pendidikan anak usia dini, sedangkan pada pasal 28disebutkan bahwa pendidikan anak usia dini diselenggarakan sebelum jenjang pendidikan dasar dan dapat diselenggarakan melalui jalur pendidikan formal, nonformal, dan informal.Pengertian PAUD adalah pendidikan anak usia dini suatu upaya pembinaan yang ditujukan kepada anak sejak lahir sampai usia enam tahun yang dilakukan melalui pemberian rangsangan pendidikan untuk membantu pertumbuhan dan perkembangan jasmani dan rohani agar anak memiliki kesiapan dalam memasuki pendidikan lebih lanjut (UU No. 20/2003 tentang Sisdiknas Bab 1, pasal 1, butir $14)$. 


\section{DAFTAR PUSTAKA}

Feist, J., dan Gregory J. F. 2014. Theories of Personality Teori Kepribadian (Terjemahan Buku 2 Edisi 7). Jakarta: Salemba Humanika.

Ginanjar, A. A. 2006. ESQ. Emotional Spritual Quetion. Jakarta: Arga.

Husein, Teuku Kemal. 2005. Brain Power Permainan Kreatif Berbasis Topik. Penerbit Erlangga.

Jalaludin, H. 2011. Psikologi Agama. PT. Jakarta: Raja Grafindo Persada.

Jamaris, Martini. 2006. Perkembangan dan Pengembangan Anak Usia Taman Kanak-Kanak. Jakarta: Gramedia.

Kajeng, I N., dkk. 1999. Sarasamuccaya. Surabaya: Paramita.

Kamtini. 2005. Bermain Melalui Gerak dan Lagu. Jakarta: Direktorat Pembinaan Pendidikan Tenaga Kependidikan dan Ketenagaan Perguruan Tinggi.

Kemendikas. 2010. Pembinaan Pendidikan Karakter di Sekolah Menengah Pertama. Jakarta.

Moleong, Lexy J. 2010. Metodologi Penelitian Kualitatif. Bandung: Remaja Rosdakarya.

Papalia, Diane E., dan Ruth Duskin Feldman. 2014. Experience Human Development Menyelami Perkembangan Manusia (Terjemahan Buku 1 Edisi 12). Jakarta: Salemba Humanika.

Rinayati, Zen. 2018. Increasing Religious Value Throught Singing Methods to Student of Kindergarden. Jurnal PAUD. Vol. 2 No. 1. Juni 2018 page $01-136$.

Suasthi, I.G.A., dan I Ketut Pande Suastawa. 2019. Perkembangan Peserta Didik. Mengoptimalkan Tumbuh Kembang Anak. Edisi Revisi. Denpasar: UNHI Press.

Suasthi, I.G.A., dan I Ketut Pande Suastawa. 2014. Psikologi Agama Menyeimbangkan Pikiran Jiwa dan Raga. Perspektif Agama Hindu. Edisi Revisi. Denpasar: Adi Putra.

Suda, I Ketut. 2018. Membentuk Karakter Anak (Melalui Seni Melukis). Denpasar: PT Jaya Widyaduta Susilowindradini. (TT). Psikologi Perkembangan: Masa Remaja. Surabaya: Usaha Nasional.

Wiana, I Ketut. 2007. Tri Hita Karana Menurut Konsep Hindu. Surabaya: Paramita.

Widana, I Gusti Ketut., dkk, 2016. Implementasi Nilai Pendidikan Karakter dalam Cerita Aranyaka Kanda di Suta Dharma School Ubud Gianyar. (penelitian tidak dipublikasikan).

Zubaedi. 2015. Desain Pendidikan Karater. Konsepsi dan Aplikasinya dalam Lembaga Pendidikan. Prenadamedia Group. 